\title{
Effects of Hexachlorophene, a Chemical Accumulating in Adipose Tissue, on Mouse and Human Mesenchymal Stem Cells
}

\author{
Monika Leśniak $^{1} \cdot$ Robert Zdanowski $^{1}\left[\right.$ Milena Suska $^{1} \cdot$ Aleksandra Brewczyńska $^{1} \cdot$

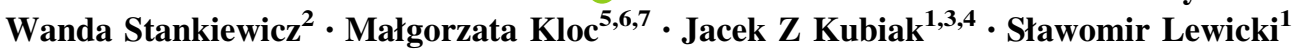

Received: 16 August 2017/Revised: 3 November 2017/ Accepted: 20 November 2017/Published online: 8 January 2018

(C) The Author(s) 2018. This article is an open access publication

\begin{abstract}
The hexachlorophene (HCP) is a highly lipophilic chlorinated bisphenol present in hygienic and dermatological products. The HCP accumulates preferentially in adipose tissue that is a privileged source of mesenchymal stem cells (MSCs). The evaluation of the potential effects of HCP on MSCs is important for their medical application. Here we examined the effects of HCP on murine adipose tissue-derived stem cells (ADSCs) and human umbilical cord-derived stem cells (UCSCs) in cell culture. We found that $10^{-4}$ and $10^{-5} \mathrm{M} \mathrm{HCP}$ inhibits proliferation, osteogenesis and increases apoptosis of ADSCs and UCSCs. While the effect of HCP on proliferation and differentiation potential of these two cell lines was similar, the UCSCs appeared much more resistant to HCP-induced apoptosis than ADSCs. These results suggest that the adipose tissue-derived ADSCs have higher sensitive for HCP than umbilical cord-derived UCSCs and indicate that the umbilical cord can be a preferable source of MSCs for prospective medical applications in the future.
\end{abstract}

Keywords Hexachlorophene $\cdot$ Mesenchymal stem cells $\cdot$ Adipose tissue $\cdot$ Unbilical cord $\cdot$ Apoptosis

Robert Zdanowski

rztox@yahoo.com

1 Departament of Regenerative Medicine and Cell Biology, Military Institute of Hygiene and Epidemiology, Kozielska 4 Street, 01163 Warsaw, Poland

2 Department of Microwave Safety, Military Institute of Hygiene and Epidemiology, Kozielska 4 Street, 01163 Warsaw, Poland

3 CNRS, UMR 6290, Institute of Genetics and Development of Rennes, Cell Cycle Group, 35043 Rennes, France

4 UEB, UMS CNRS 3480, Faculty of Medicine, University Rennes 1, 35043 Rennes, France

5 The Houston Methodist Research Institute, 6670 Bertner Ave, Houston, TX 77030, USA

6 Department of Surgery, The Houston Methodist Hospital, 6565 Fannin Street, Houston, TX 77030, USA

7 MD Anderson Cancer Center, Department of Genetics, The University of Texas, 1515 Holcombe Blvd, Houston, TX 77030, USA

\section{Introduction}

The ability of pluripotent stem cells to differentiate into osteoblasts, chondrocytes, myoblasts, adipocytes and neurons makes them irreplaceable tool in regenerative medicine $[1,2]$. The stem cells isolated from adult human tissue contain a high percentage of Mesenchymal Stem Cells (MSCs). Studies performed in recent years showed that the adipose (fat) tissue might be a preferred source of MSCs due to its availability and ease of acquisition. However, the adipose tissue has affinity for and accumulates highly lipophilic chemicals, such as insecticides, polychlorinated biphenyls, hexachlorophene, polycyclic aromatic hydrocarbons, which are present in food (especially produced in industrialized farms) and personal hygiene products [3]. These chemicals constitute a potential human health risk; a sudden loss of fat tissue after intense exercise or extreme weight loss causes rapid release of adipose tissue-accumulated chemicals into the blood, liver, kidneys and brain. In addition, these chemicals may affect proliferation and/or differentiation of adipose tissue-derived MSCs. 
Hexachlorophene [2,2'-methylenebis-(3,4,6trichlorophenol)] (HCP) is a chlorinated bisphenol with strong bacteriostatic properties against many Gram-positive bacteria (including Staphylococcus) [4] that is used in soaps, creams and dermatological preparations. Because HCP is very resistant to biotransformation it accumulates in the environment and bioaccumulates in food chain [5]. Animal studies have shown a clear chronic negative effect of HPC on human health. HCP administered orally or vaginally in high doses was embryotoxic and teratogenic in rats [6]. Lokanatha et al. [7] showed that HCP had, through the inhibition of succinate dehydrogenase, neurotoxic effects on rat brain. The poisoning symptoms of HCP are neurologic, cardiovascular, respiratory, gastrointenstinal and dermatological. The range of lethal dose in adult human is 2-10 $\mathrm{g}$ per $\mathrm{kg}$ of body mass [8]. However, the minimal lethal dose is unknown. Because of its high hydrophobicity the HCP rapidly accumulates in adipose tissues and central nervous system (CNS). Within the nervous system the myelin has a significant affinity for HCP. Experimental studies showed inhibitory effect of HCP on synthesis of myelin possibly by inhibition of oxidative phosphorylation [5]. HCP is metabolized in the liver by glucuronidation and is excreted into bile.

Here we investigated the effect of various concentrations of HCP on the proliferatation, apoptosis and differentiation into osteaoblasts of MSCs from two different sources: adipose tissue and umbilical cord. We also tested whether preincubation of MSCs with HCP affects their differentiation into osteoblasts.

\section{Materials and methods}

\subsection{Animals and human tissues samples}

Fat tissue was isolated form 8 weeks C57BL/6 mice. Mice were sacrificed by anesthetic overdose (pentobarbital, 400 mg/kg; Polypharm S.A., Warsaw, Poland). Fat tissue was isolated from gonadal and kidney localization under aseptic conditions (laminar flow cabinet) and transferred to falcon probe which contained $10 \mathrm{ml}$ PBS with antibiotics penicillin-streptomycin (500 IU/ml, Thermo Fisher Scientific, Poland) until use.

Human umbilical cord samples were downloaded postpartum. After isolation umbilical cord samples were transferred to falcon probe which contained $30 \mathrm{ml}$ PBS with antibiotics (penicillin-streptomycin (500 IU/ml, Thermo Fisher Scientific, Poland) until use.

\subsection{Cell isolation and culture}

Experiments were performed on two primary cells lines: adipose derived stem cells (ADSCs)—mesenchymal stem cells isolated from adipose tissue of C57BL/6 mice, and umbilical cord stem cells (UCSCs)—mesenchymal stem cells isolated from human umbilical cord.

ADSCs were isolated by the method described by Gronthos et al. [9] with our own modification. The adipose tissue was digested in type 1 collagenase $(1 \mathrm{mg} / \mathrm{ml}$; Sigma Aldrich, Poland) for $1 \mathrm{~h}$ at $37^{\circ} \mathrm{C}$ with shaking in water bath. Digested tissue was strained through $40 \mu \mathrm{m}$ strainer, washed with culture medium (DMEM F12, 10\% FBS, penicillin/streptomycin, Thermo Fisher Scientific, Poland) and centrifuged for $5 \mathrm{~min}$ at $500 \times \mathrm{g}$. The cells recovered in pellets were counted and seeded onto 6 well dishes at $1.5 \times 10^{6}$ cells/well and cultured at $37{ }^{\circ} \mathrm{C}$ in $5 \% \mathrm{CO}_{2}$. The cell culture medium was changed after $24 \mathrm{~h}$. Cells were grown to $90 \%$ confluency, washed with PBS, harvested by trypsinization $(0.25 \%$ trypsin in PBS) and seeded into $75 \mathrm{~cm}^{2}$ culture bottles at $10^{6}$ cells/bottle. Cells were cultured up to 18 passage. The proliferation time between passages equals $96 \mathrm{~h}$.

Human UCSCs were isolated from umbilical cord Wharton's jelly by the method described by Ishige et al. [10] with our own modification. Fragments of umbilical cord were cut into small pieces and cultured at $37{ }^{\circ} \mathrm{C}$ in $5 \%$ $\mathrm{CO}_{2}$ in DMEM medium containing $4.5 \mathrm{~g} / 1$ of glucose (Thermo Fisher Scientific, Poland), 20\% FBS (Thermo Fisher Scientific, Poland) and penicillin/streptomycin (Thermo Fisher Scientific, Poland). The culture medium was replaced once a week to achieve $90 \%$ cell confluency. Cells were rinsed twice with PBS (Thermo Fisher Scientific, Poland), trypsinized (0.25\% trypsin in PBS, Thermo Fisher Scientific, Poland) and seeded in $25 \mathrm{~cm}^{2}$ cell culture flasks at $3 \times 10^{5}$ cells/flask. Cells were cultured up to 24 passage. The proliferation time between passages equals $72 \mathrm{~h}$.

After 2nd and 3rd passage, ADSCs and UCSCs cells were frozen in culture medium with 10\% DMSO (Sigma Aldrich, Poland) and stored under liquid nitrogen.

Mesenchymal stem cells isolated from mouse adipose tissue and human umbilical cord were derived from tissue lipophilic compounds free.

\subsection{Flow cytometry analysis}

The ADSCs and UCSCs were collected using Acutase (BD Biosciences, Poland) and washed in PBS (Sigma Aldrich, Poland). The presence of surface markers: CD29 ${ }^{+}$, $\mathrm{CD}_{105}{ }^{+}, \mathrm{CD}_{106}{ }^{+}$and $\mathrm{CD}^{-} 5^{-}$(Becton-Dickinson, Poland) was determined in 2nd and 3rd passage cells using 
flow cytometer FACS Calibur and the results were analyzed by Cell Quest pro software (both from BD, USA).

\subsection{Hexachlorophene preparation}

HCP was purchased from Sigma Aldrich, Poland. HCP was dissolved in $10^{-1} \mathrm{M}$ DMSO (Sigma Aldrich, Poland), aliquoted and stored in glass bottles in the dark at $4{ }^{\circ} \mathrm{C}$. We have used $10^{-7}-10^{-4} \mathrm{M} \mathrm{HCP}$ concentration in the culture medium. The DMSO content in the samples was $0.01 \%$.

\subsection{Proliferation assays}

\subsubsection{Cell culture}

ADSCs or UCSCs in a log phase stage of growth were harvested by trypsinization $(0.05 \%$ solution, Thermo Fisher Scientific, Poland) and pelleting at $300 \times g$ for $5 \mathrm{~min}$. Cell pellets were resuspended in culture medium and $1.5 \times 10^{4}$ cells $/ \mathrm{ml}$ were seeded into 96 -well plate $(200 \mu \mathrm{l}$ per well). After $24 \mathrm{~h}$ cells were washed twice with PBS, and $10^{-7}$ $10^{-4} \mathrm{M} \mathrm{HCP}$ was added in fresh culture medium. Control cells were grown in culture medium without HCP and with $0.01 \%$ DMSO. The proliferation assay will be evaluated using three independent cell number comparison tests which were performed as previously described [11].

\subsubsection{MTT assay}

24, 48 and $72 \mathrm{~h}$ after HCP addition the culture medium was discarded and fresh culture medium containing MTT ( $1 \mathrm{mg} / \mathrm{ml}$, Sigma Aldrich, Poland) was added directly to the wells. After $2 \mathrm{~h}$ incubation $\left(37{ }^{\circ} \mathrm{C}, 5 \% \mathrm{CO}_{2}\right.$, ) the medium was discarded, cells were rinsed 3 times with PBS and to dissolve the formazan crystals the $100 \mu \mathrm{l}$ of DMSO was added to the wells. The absorbance was measured at $570 \mathrm{~nm}$ using FLUOstar Omega reader (BMG Labtech, Sweden).

\subsubsection{Neutral Red assay}

24, 48 and $72 \mathrm{~h}$ after HCP addition the culture medium was discarded and fresh culture medium containing Neutral Red ( $25 \mathrm{mg} / \mathrm{ml}$; Sigma Aldrich, Poland) was added directly to the wells. After $2 \mathrm{~h}$ of incubation $\left(37{ }^{\circ} \mathrm{C}, 5 \% \mathrm{CO}_{2}\right.$, ) the medium was discarded and cells were rinsed 3 times with PBS. Subsequently, in order to dissolve the pigment, cells were rinsed with $100 \mu \mathrm{l}$ of $1 \%$ acetic acid, $50 \%$ ethanol, 49\% water solution (Sigma Aldrich). The absorbance was measured at $570 \mathrm{~nm}$ using FLUOstar Omega reader (BMG Labtech, Sweden).

\subsubsection{Sulforodamine B assay}

24, 48 and $72 \mathrm{~h}$ after HCP addition the culture medium was discarded and cells were fixed with $50 \%$ trichloroacetic acid (Sigma Aldrich, Poland,; $100 \mu \mathrm{l}$ per well, $1 \mathrm{~h}, 4{ }^{\circ} \mathrm{C}$ ). Fixed cells were washed 3 times in water, air dried and $100 \mu \mathrm{l}$ of sulforodamine B $(0.4 \%$ in $1 \%$ acetic acid; Sigma Aldrich, Poland) was added. After 30 min incubation cells were washed with $1 \%$ acetic acid 4 times, air dried and $10 \mathrm{mM}$ Trisma ${ }^{\circledR}$ base $(100 \mu \mathrm{l} /$ well; Sigma Aldrich, Poland) was added to dissolve the pigment. The fluorescence was measured at excitation $570 \mathrm{~nm}( \pm 10)$ and emission $590 \mathrm{~nm}( \pm 10)$ using FLUOstar Omega reader (BMG Labtech, Sweden).

\subsection{Apoptosis assay}

ADSCs or UCSCs in a log phase growth were harvested and seeded at $3 \times 10^{4}$ cells/well and $5 \times 10^{4}$ cells/well, respectively, in $24-$ well plate $(1 \mathrm{ml} /$ well $) .24 \mathrm{~h}$ later cells were incubated with $10^{-7}-10^{-4} \mathrm{M} \mathrm{HCP}$. Control cells were grown in culture medium without HCP and with $0.01 \%$ DMSO. After 24 and $72 \mathrm{~h}$ incubation cells were washed twice with PBS and pelleted $(500 \times g, 5 \mathrm{~min})$. Cell pellets were washed twice with PBS, centrifuged and resuspended in annexin binding buffer with addition of $4.5 \mu \mathrm{l}$ annexin V-FITC antibody (eBioscence, Poland) and $8 \mu$ propidium iodide $1 \mathrm{mg} / \mathrm{ml}$ (Sigma Aldrich, Poland). After $20 \mathrm{~min}$ incubation cells were washed with PBS and analyzed by flow cytometry (FACS Calibur, BD, USA). Evaluation of live, apoptotic and necrotic cells was performed using Cell Quest software.

\subsection{Osteogenesis of ADSCs and UCSCs}

\subsubsection{ADSCs and UCSCs osteogenesis in the presence of HCP in osteogenic induction medium}

ADSCs or UCSCs in a log phase were plated in 24-well plate at $4 \times 10^{4}$ cells/well (ADSCs) and $2 \times 10^{4}$ cells/well (UCSCs). Cells were grown to $95 \%$ confluency and osteogenic induction medium (DMEM $4.5 \mathrm{~g} / 1 \mathrm{D}-$ Glucose or DMEM F12, $10 \%$ FBS, $200 \mu \mathrm{M}$ L-ascorbic acid 2-phosphate, $100 \mathrm{nM}$ dexamethasone, $10 \mathrm{mM} \beta$-Glycerophosphate - all from Sigma Aldrich, Poland) was added directly to the wells. The composition of the osteogenic induction medium was described by Kim et al. [12] and Wang et al. [13] and the concentration of the individual compounds were selected experimentally by us. The HCP was added at $10^{-7}-10^{-4} \mathrm{M}$. The control cells were cultured in osteogenic induction medium without HCP and with $0.01 \%$ DMSO (positive control) or culture medium without osteogenic supplement, HCP and with $0.01 \%$ DMSO 
(negative control). Cells were cultured for 3 weeks and medium was changed every 3-4 days.

\subsubsection{ADSCs and UCSCs preincubation with HCP followed by osteogenesis without HCP in osteogenic induction medium}

Mesenchymal Stem Cells in a log phase stage of growth were plated in $25 \mathrm{~cm}^{2}$ flasks at density $4 \times 10^{5}$ cells/flask (ADSCs) and $2 \times 10^{5}$ cells/flask (UCSCs). $24 \mathrm{~h}$ later cells were treated with different concentrations $\left(10^{-7}-10^{-4} \mathrm{M}\right)$ of HCP. Cells were grown to 90-95\% confluence, harvested by trypsinization and seeded in 24-well plate at $4 \times 10^{4}$ cells/well (ADSCs) and $2 \times 10^{4}$ cells/well (UCSCs). After cells had formed monoleyer they were cultured for 3 weeks in osteogenic induction medium without HCP. Medium was changed every 3-4 days. The positive control cells were cultured in osteogenic induction medium without HCP and with $0.01 \%$ DMSO. The negative control cells were cultured in medium without osteogenic supplements and with $0.01 \%$ DMSO.

\subsubsection{Alizarin red staining}

After 3 weeks of osteogenic differentiation cells were fixed in 4\% paraformaldehyde (Sigma Aldrich, Poland) for 20 min. Fixed cells were washed with PBS and stained with Alizarin Red S ( 2 g/100 ml of distilled water; Sigma Aldrich, Poland) $\mathrm{pH} 4.1-4.3$ for $20 \mathrm{~min}$.

Alizarin Red S stains red the calcium deposits formed in the differentiated cells (osteoblasts) The results are presented using a five-point visual scale: undifferentiated cells $(-)$, differentiated cells depending on the intensity of staining $(+),(++),(+++),(++++)$.

\subsection{Statistical analysis}

Statistical analysis was performed using unpaired t-tests and one-or two-way analysis of the variance, followed by the Tukey test or Bonferroni correction (in the case of a normal distribution) or non-parametric Kruskal-Wallis and Mann-Whitney $U$ tests (in the case of abnormal distribution). Assessment of the distribution of data was evaluated using the Shapiro-Wilk test. GraphPad Prism software was used (ver. 5; GraphPad Software, Inc., La Jolla, CA, USA). $p<0.05$ was a statistically significant difference.

\section{Results}

\subsection{Mesenchymal cells phenotype}

Mice adipose-derived stem cells (ADSCs), after third passage of in vitro culture, expressed CD29, CD105 and CD106 surface markers. Over 95\% of cells expressed CD29, CD105 and CD106 markers. The highest expression was found for CD29 marker. There was a weak expression of CD105 and CD106 and the CD45 positive cells were absent. The results are presented in Fig. 1.

Human UCSCs also expressed CD29, CD105 and CD106 stem cell surface markers Over 95\% of cells expressed CD29, CD105 and CD106 markers. The CD45 positive cells were absent. The highest level of expression was observed for CD29 > CD105 > CD106. The UCSCs also expressed CD73, CD90 surface markers (data not shown) and were negative for CD34 expression (data not shown). The results are presented in Fig. 2.

\subsection{Proliferation assays}

\subsubsection{ADSCs}

The results of MTT, NR and SRB, three independent cell number comparison tests, showed that there was no significant change in proliferation of ADSCs after 24-72 h treatment with $10^{-7}$ and $10^{-6} \mathrm{M} \mathrm{HCP}$ in comparison to the control. The higher concentration of HCP $\left(10^{-5}\right.$ and $10^{-4}$ M) significantly decreased ( $75 \%$ of the control value, $p<$ $0.0001)$ cell proliferation after $72 \mathrm{~h}$. Toxic effect of the highest concentration $\left(10^{-4} \mathrm{M}\right)$ of $\mathrm{HCP}$ was already visible after $24 \mathrm{~h}$ of treatment. Figure 3 shows the results (presented as a mean \pm SEM) from 3 independent experiments.

\subsubsection{UCSCs}

The results of MTT, NR and SRB proliferation assays showed that there was no significant change in proliferation of UCSCs after 24-72 $\mathrm{h}$ treatment with $10^{-7}$ and $10^{-6} \mathrm{M}$ HCP in comparison to the control. There was slight, but statistically significant increase of proliferation after $48 \mathrm{~h}$ treatment with $10^{-6} \mathrm{M} \mathrm{HCP}(p<0.05)$ and $72 \mathrm{~h}$ treatment with $10^{-7} \mathrm{M}$ HCP $(p<0.05)$ when compared to the control. The highest concentration of HCP $\left(10^{-4} \mathrm{M}\right)$ caused significant reduction of cell proliferation, especially after $72 \mathrm{~h}$ treatment (Fig. 4). The results from 3 independent experiments are shown as a mean \pm SEM. 

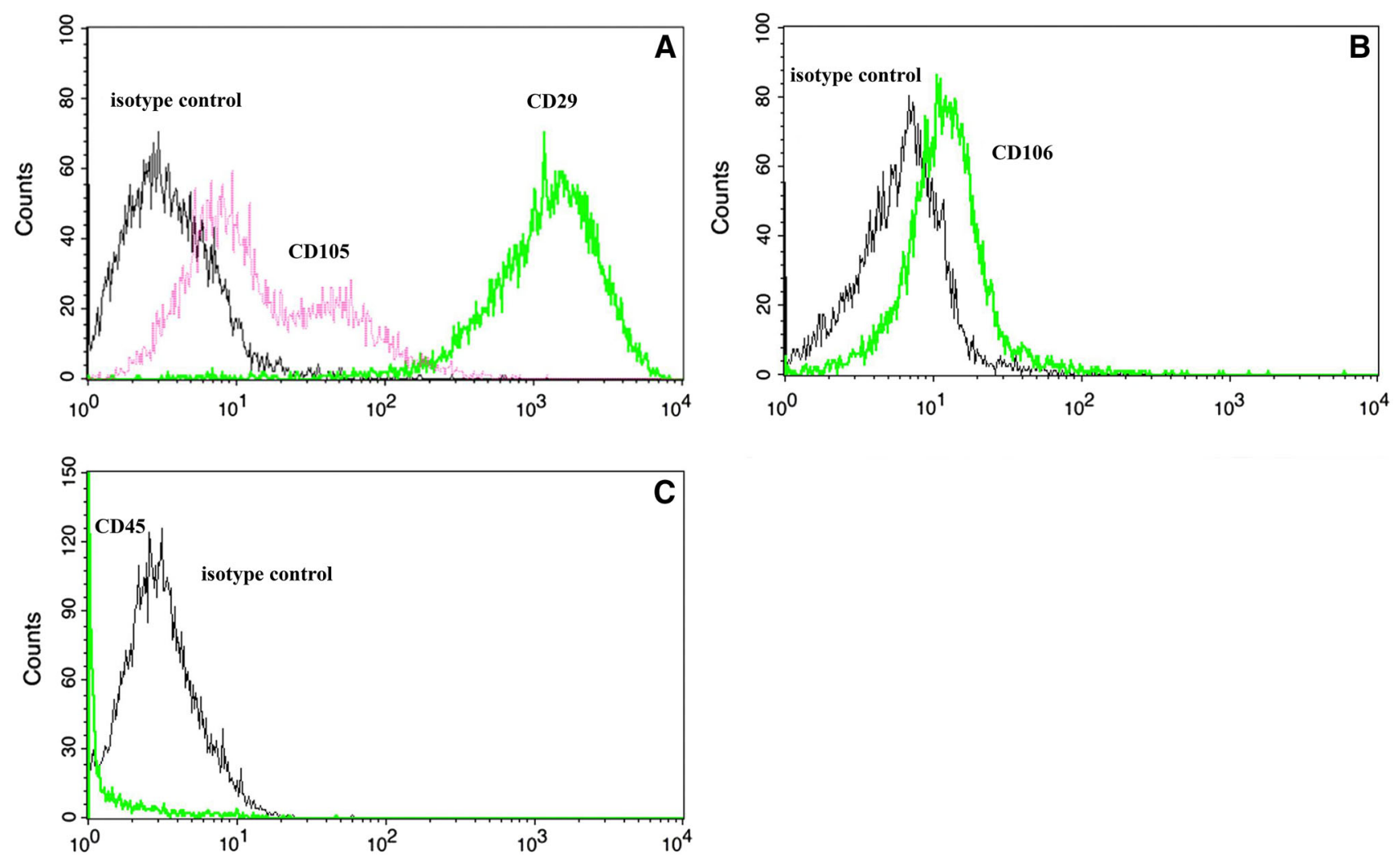

Fig. 1 Stem cell surface markers expressed by ADSCs A CD 105, CD 29, B CD 106 and C CD 45
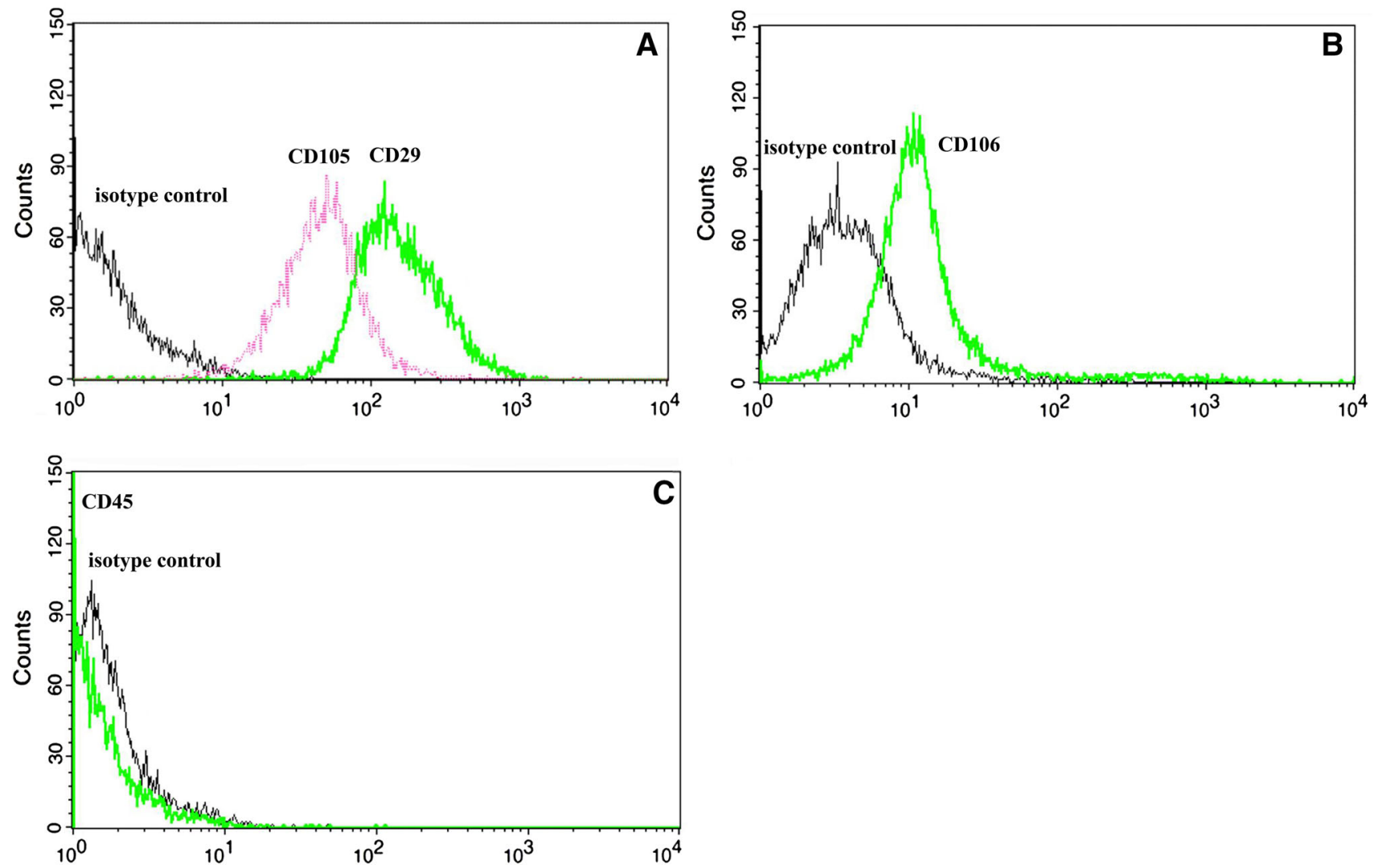

Fig. 2 Stem cells surface markers expressed by UCSCs A CD 105, CD 29, B CD 106 and C CD 45 


\section{MTT}
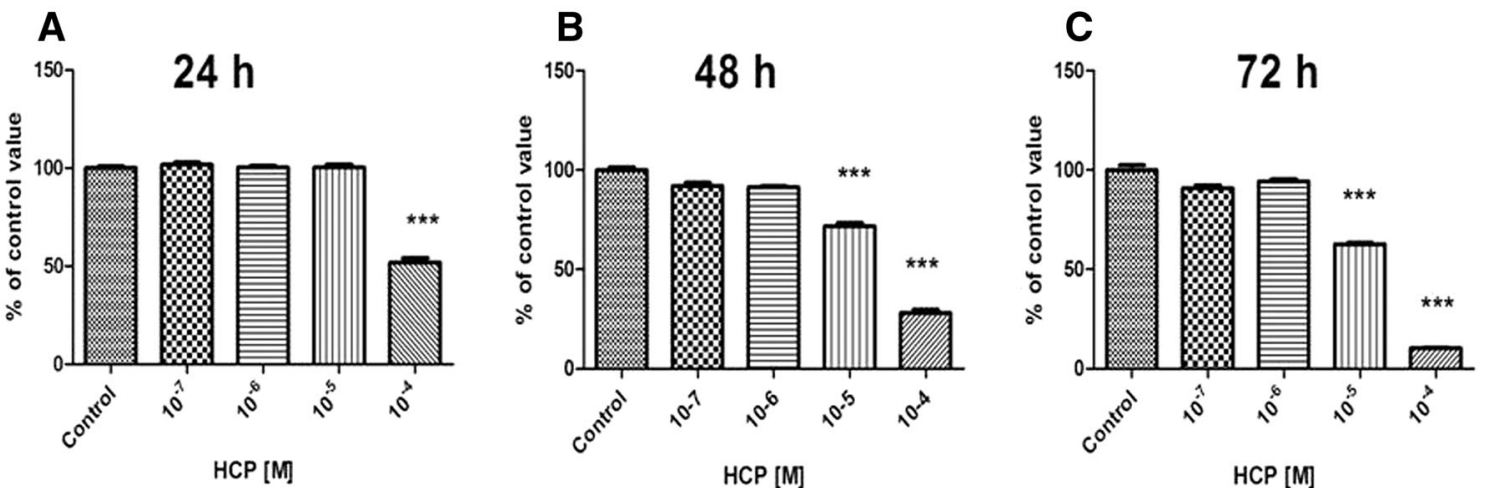

NR
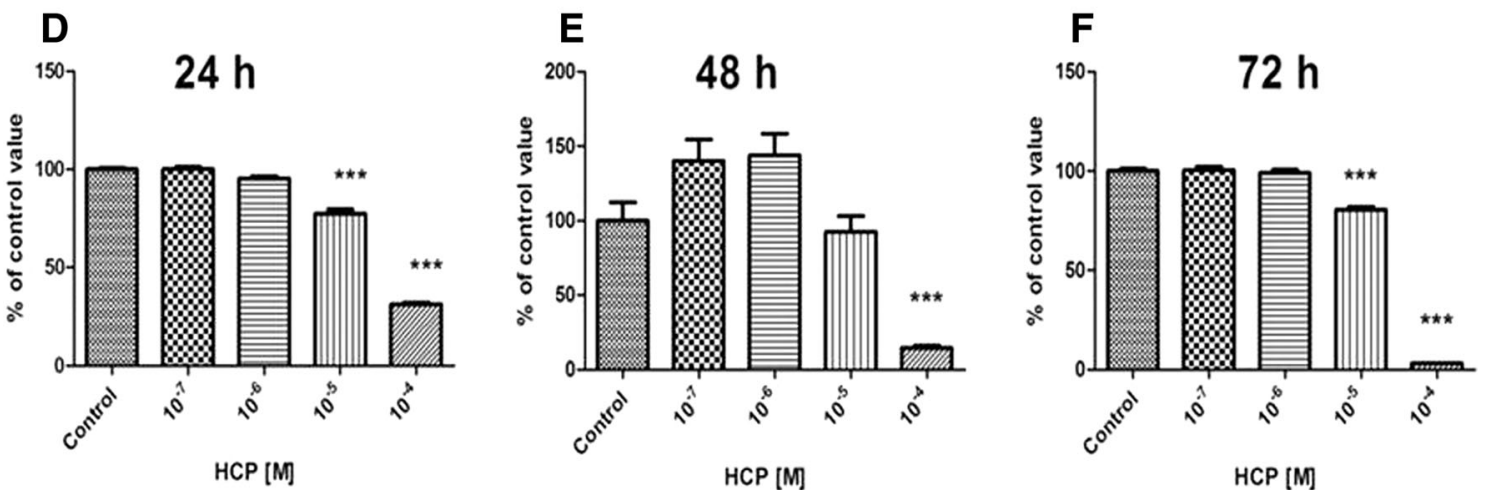

\section{SRB}
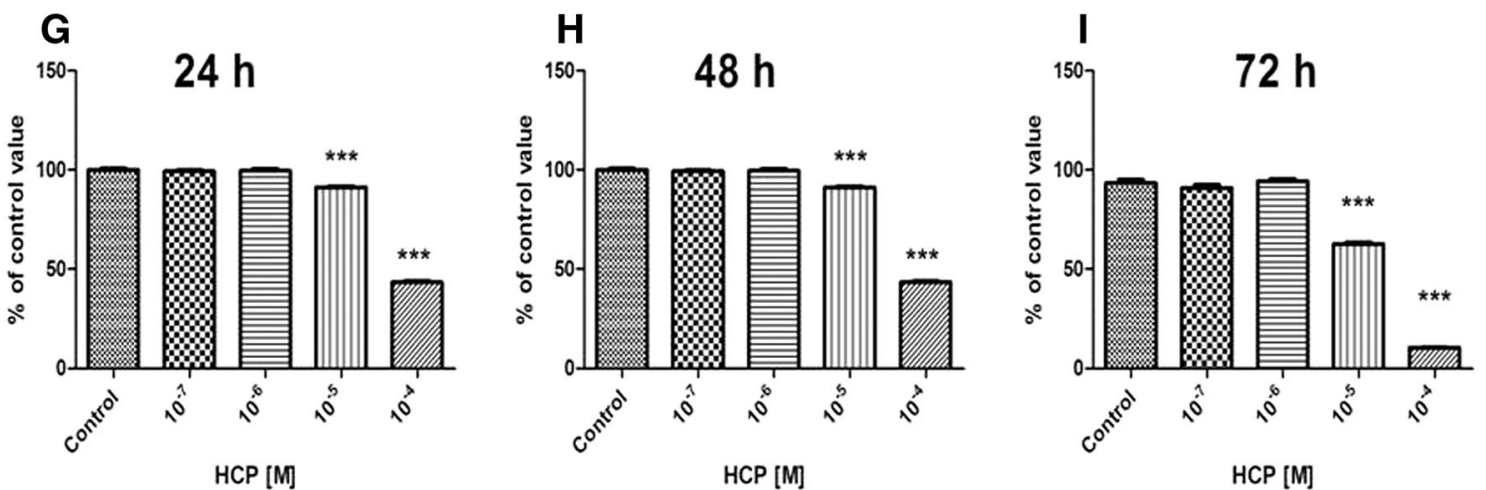

Fig. 3 Effect of HCP treatment on ADSCs proliferation assessed by MTT assay A 24 h, B 48 h, C 72 h; NR assay D 24 h, E 48 h, F 72 h and SRB assay, G 24 h, H 48 h, I 72 h (mean \pm SEM)

\subsection{Apoptosis assay}

\subsubsection{ADSCs}

The treatment (24 and $72 \mathrm{~h}$ ) with HCP $\left(10^{-7}\right.$ and $\left.10^{-6} \mathrm{M}\right)$ did not affect the number of necrotic or apoptotic ADSC cells when compared to the control (Fig. 5A, B). However, there was statistically significant dose-dependent decrease in the percentage of live cells after treatment with $10^{-5}$ and $10^{-4} \mathrm{M}$ HCP. HCP in concentration $10^{-5}$ and $10^{-4} \mathrm{M}$ caused significant increase in necrosis and especially in apoptosis. The highest number of necrotic and apoptotic cells were found in $10^{-4} \mathrm{M} \mathrm{HCP}$ after $72 \mathrm{~h}$ treatment 


\section{MTT}
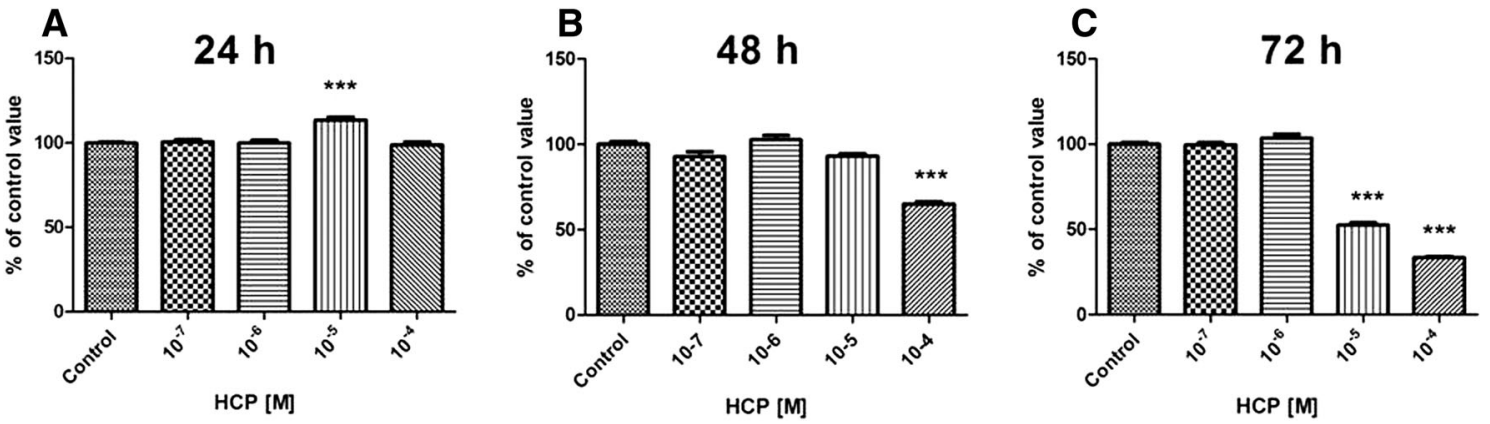

NR
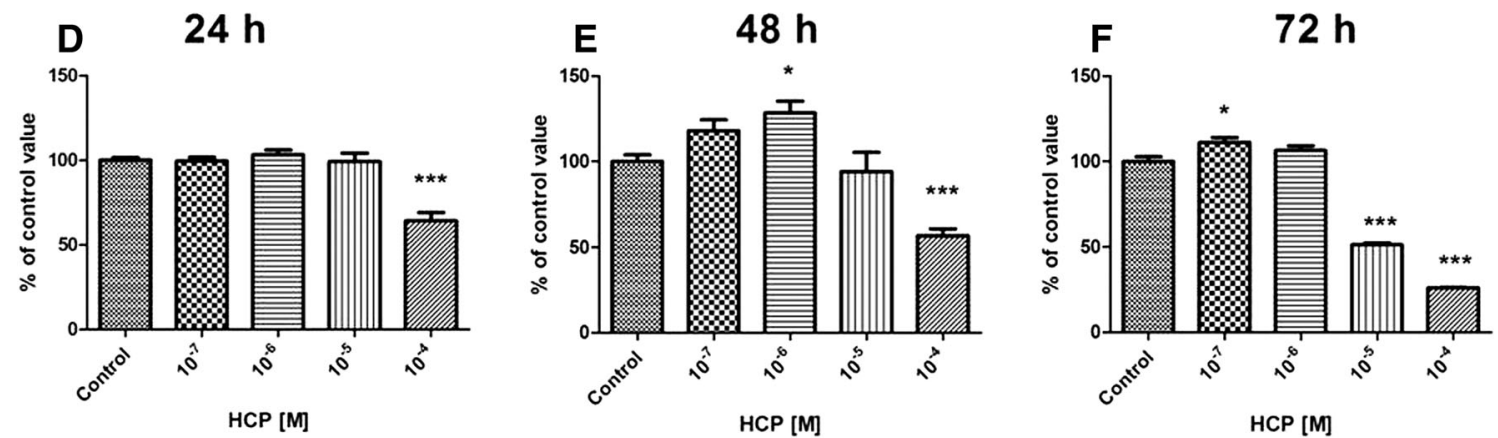

\section{SRB}
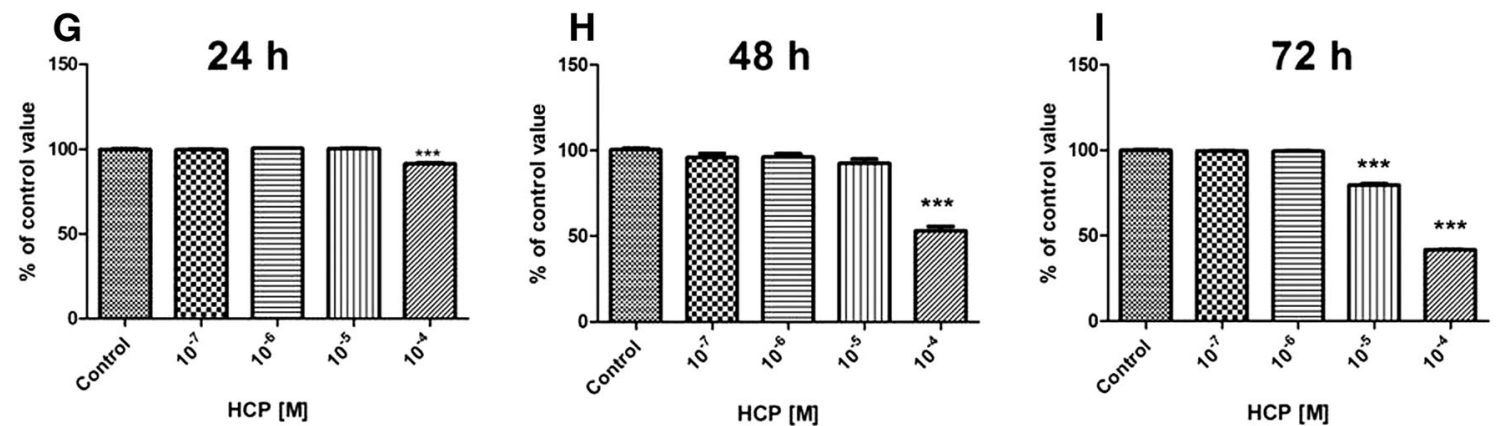

Fig. 4 Effect of HCP treatment on UCSCs proliferation assessed by MTT assay A 24 h, B 48 h, C 72 h; NR assay D 24 h, E 48 h, F 72 h and SRB assay, G 24 h, H 48 h, I 72 h (mean \pm SEM)

$(p<0.0001)$ (Fig. 5B). The results from 3 independent experiments are shown as a mean.

\subsubsection{UCSCs}

Similar to the results obtained for ADSCs, the $10^{-7}$ and $10^{-6}$ M HCP did not affect the percentage of live UCSCs when compared to the control group (Fig. 6A, B). However, the UCSCs were less susceptible to HCP treatment than ADSCs. After $24 \mathrm{~h}$ HPC treatment in concentration form $10^{-7}$ to $10^{-4} \mathrm{M}$ there was no significant change in the percentage of viable cells or in the percentage of necrotic or apoptotic cells. After $72 \mathrm{~h}$ HCP treatment in concentration of $10^{-5}$ and $10^{-4} \mathrm{M}$ there was statistically significant dose depended decrease in the percentage of viable cells (about 17\%, $p<0.0001$, and about $28 \%$ $p<0.001$, respectively). In concentration of $10^{-5} \mathrm{M} \mathrm{HCP}$ the cells mainly died by apoptosis and there was no significant increase in necrosis. The highest concentration of HCP $\left(10^{-4} \mathrm{M}\right)$ caused increase in both necrosis (about $930 \%, p<0.001$ ) and apoptosis (about $630 \%, p<0.001$ ) (Fig. 6B). The results from 3 independent experiments are shown as mean values. 

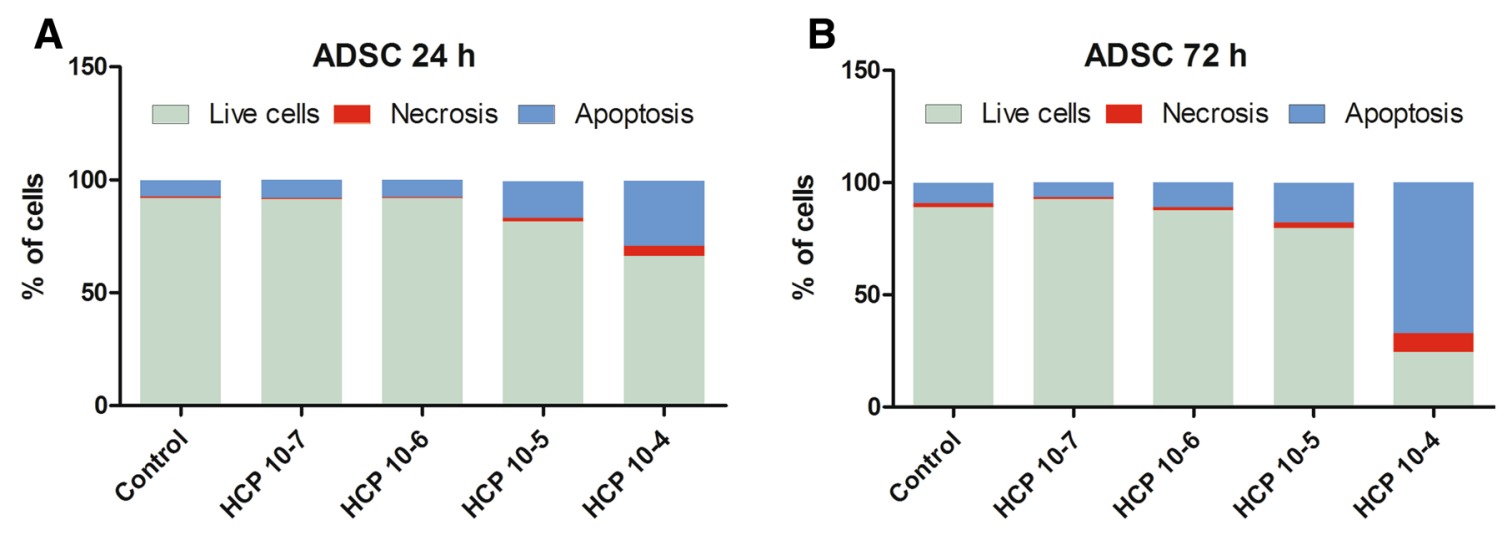

Fig. 5 A, B Effect of HCP on ADSCs apoptosis and necrosis after 24 and $72 \mathrm{~h}$ treatment
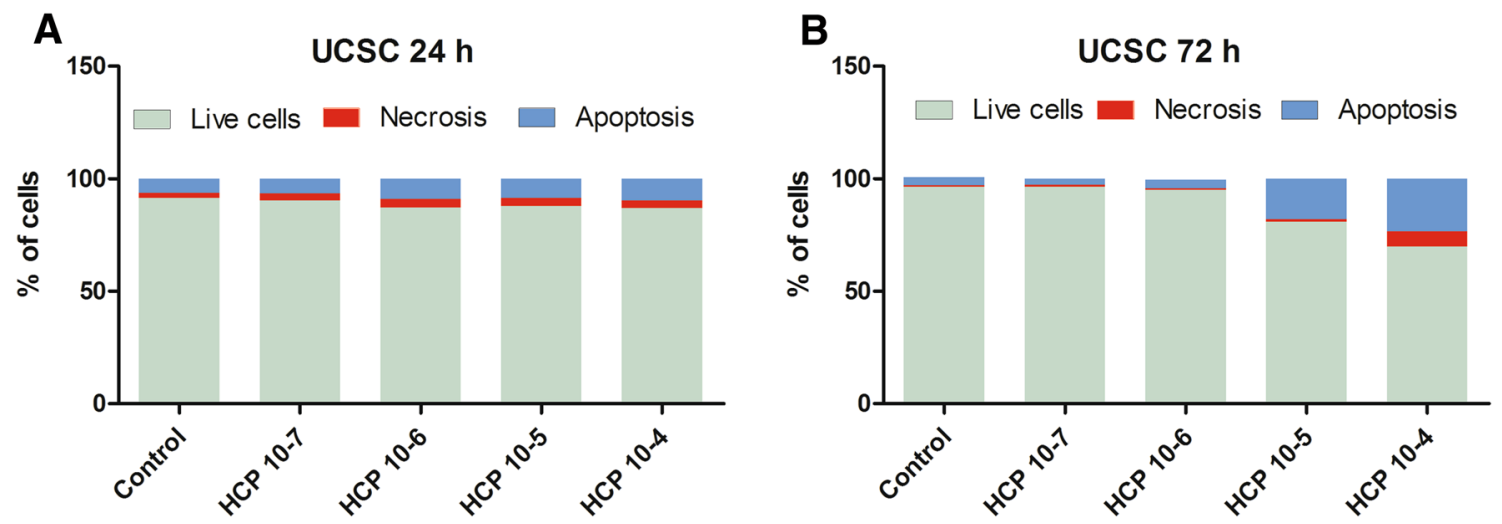

Fig. 6 A, B Effect of HCP on UCSCs apoptosis and necrosis after A 24 and B 72 h treatment

\subsection{Osteogenesis of ADSCs and UCSCs}

\subsubsection{ADSCs and UCSCs osteogenesis in the presence of $\mathrm{HCP}$ in osteogenic induction medium}

The $10^{-4} \mathrm{M}$ HCP added to the osteogenic induction medium caused death of both ADSCs and UCSCs cells before the end of experiment (not shown). The addition of $10^{-5}$ M HCP significantly inhibited osteogenesis of ADSCs and UCSCs (there was no visible calcium deposits after Alizarin Red staining Figs. 7C, 8C). Similar effect was observed for negative control (Figs. 7B, 8B). Treatment with lower concentration $\left(10^{-6}\right.$ and $\left.10^{-7} \mathrm{M}\right)$ of $\mathrm{HCP}$ resulted in lower differentiation level (Figs. 7D-E, 8D-E) when compared to the control (Figs. 7A, 8A). Results of microscopic evaluation of the intensity of Alizarin Red staining are shown in Table 1.

\subsubsection{ADSCs and UCSCs preincubation with HCP \\ followed by osteogenesis without HCP in osteogenic induction medium}

ADSCs and UCSC cells preincubated with $10^{-4} \mathrm{M}$ HCP remained undifferentiated (Figs. 9C, 10C) similar to negative control (Figs. 9B, 10B). The preincubation with HCP in lower concentration $\left(10^{-5}-10^{-7} \mathrm{M}\right)$ did not inhibit osteogenesis (Figs. 9D-F, 10D-F) but the level of differentiation was lower than in positive control (Figs. 9A, 10A). Results of the microscopic evaluation of the intensity of Alizarin Red staining are shown in Table 2.

\section{Discussion}

The ability of ADSCs to differentiate into different types of cells is widely used in tissue engineering and regenerative medicine. Several studies described the use ADSC in tissue remodeling, stimulation of peripheral nerve repair [14], functional recovery in spinal cord damage [15], diabetes treatments [16] and liver injury repair [17]. The ADSCs are also used as filler in plastic and cosmetic surgery [18] and as the autologous chondrocytes alternative for a repair of articular cartilage in the knee [19]. The ADSCs were also used, in combination with fibrin glue and a biodegradable scaffold, to repair the calvarial bone defects [20]. For all these applications the ADSCs should be isolated from healthy and young donors. 

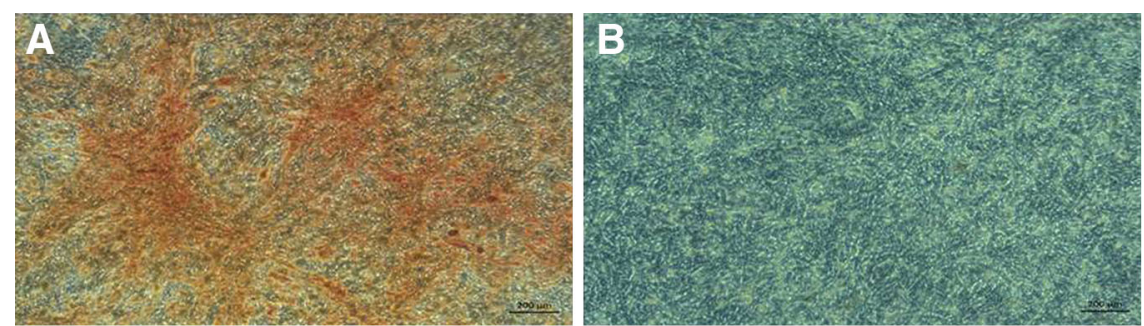

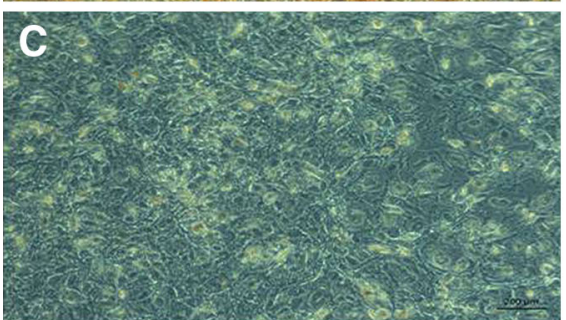

Fig. 7 Alizarin Red staining on 21th day of ADSCs osteogenesis (calcium deposits formed in the differentiated cells (osteoblasts) are orange/red color). A Positive control (differentiated cells without HCP). B Negative control (cells cultured in culture medium without

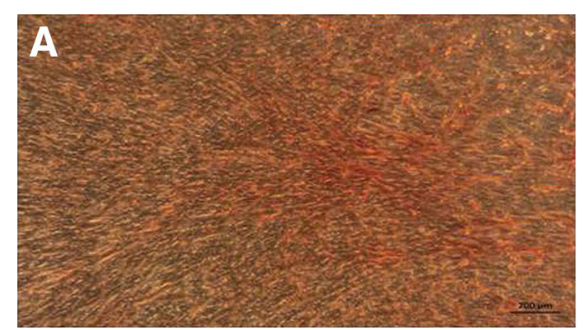

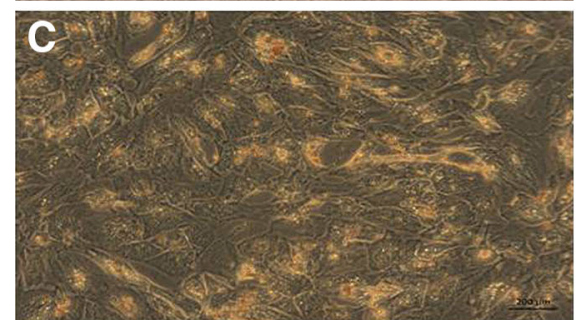

Fig. 8 Alizarin Red staining on 21th day of UCSCs' osteogenesis (calcium deposits formed in the differentiated cells (osteoblasts) are orange/red color). A Positive control (differentiated cells without HCP). B Negative control (cells cultured in culture medium without osteogenesis factors). C HCP $10^{-5} \mathrm{M}, \mathbf{D}$ HCP $10^{-6} \mathrm{M}, \mathbf{E}$ HCP $10^{-7}$ M. Images acquired by inverted light microscope (ZEISS AX10, Poland; magnification $\times 100$ )
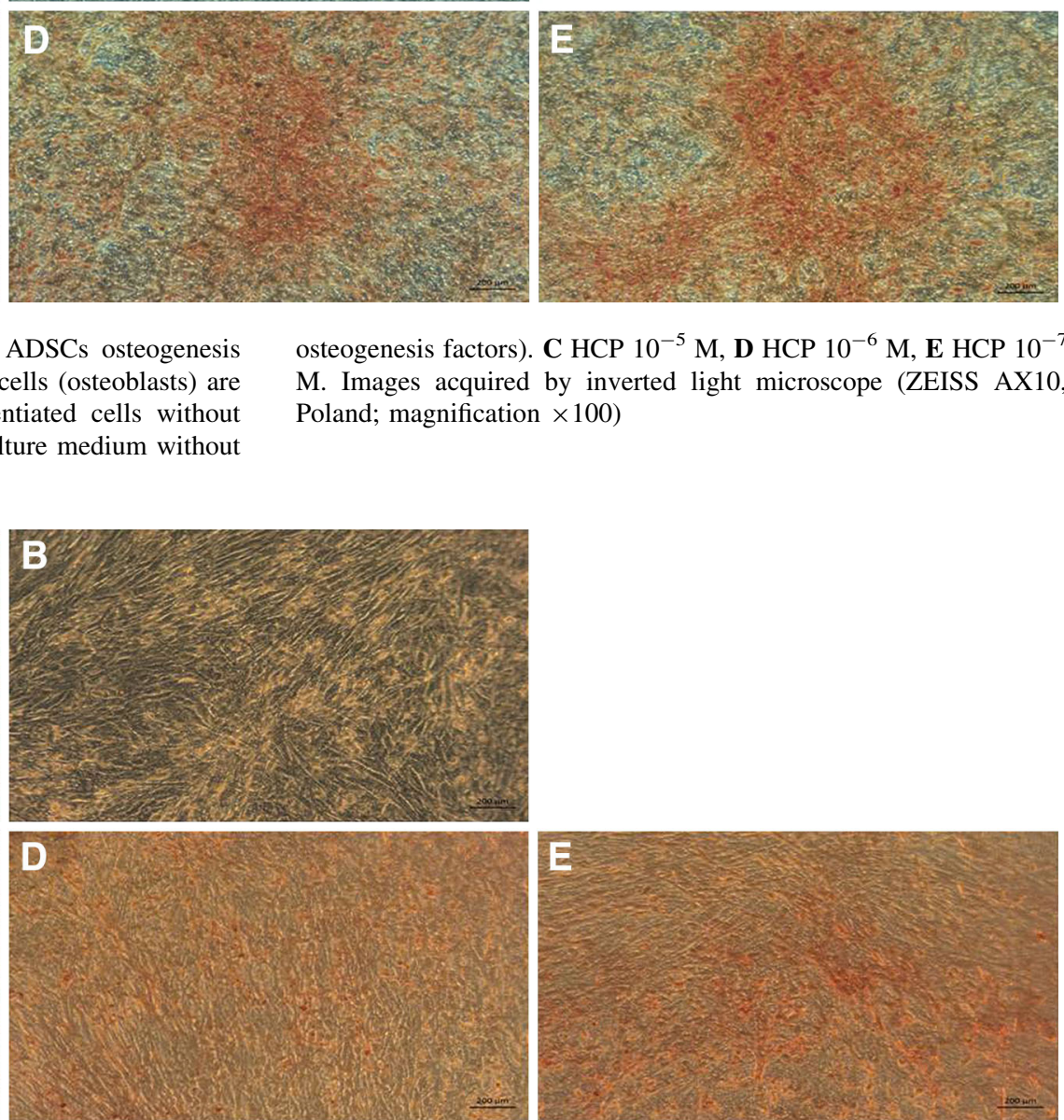

ostegenesis factors). C HCP $10^{-5} \mathrm{M}$, D HCP $10^{-6} \mathrm{M}$, E HCP $10^{-7}$ M. Images acquired by inverted light microscope (ZEISS AX10, Poland; magnification $\times 100$ )
Table 1 ADSCs and UCSCs Alizarin Red staining intensity (microscopic evaluation)

\begin{tabular}{llllll}
\hline $\begin{array}{l}\text { Stem } \\
\text { cells }\end{array}$ & Control positive & Control negative & HCP & \\
\cline { 3 - 5 } & & & $10^{-5} \mathrm{M}$ & $10^{-6} \mathrm{M}$ & $10^{-7} \mathrm{M}$ \\
\hline ADSCs & ++++ & - & - & ++ & ++ \\
UCSCs & ++++ & - & - & ++ & ++ \\
\hline
\end{tabular}

Recently, Alt et al. [21] demonstrated that the number of tissue resident ADSCs decrease significantly with the increasing donor age. The ADSCs isolated from old donors display senescent features compared with cells isolated from young donors. Li et al. [22] reported that the donor's age has the impact on proliferation of human bone marrow
MSCs. Similarly, Paxson et al. [23] showed the lower number of colony forming units, lower growth potential and telomerase activity in lung-derived MSCs from older mice. Choudhery et al. [24] reported the effect of donor age on expansion and differentiation potential of human ADSCs and showed that the ADSCs from older donors had 

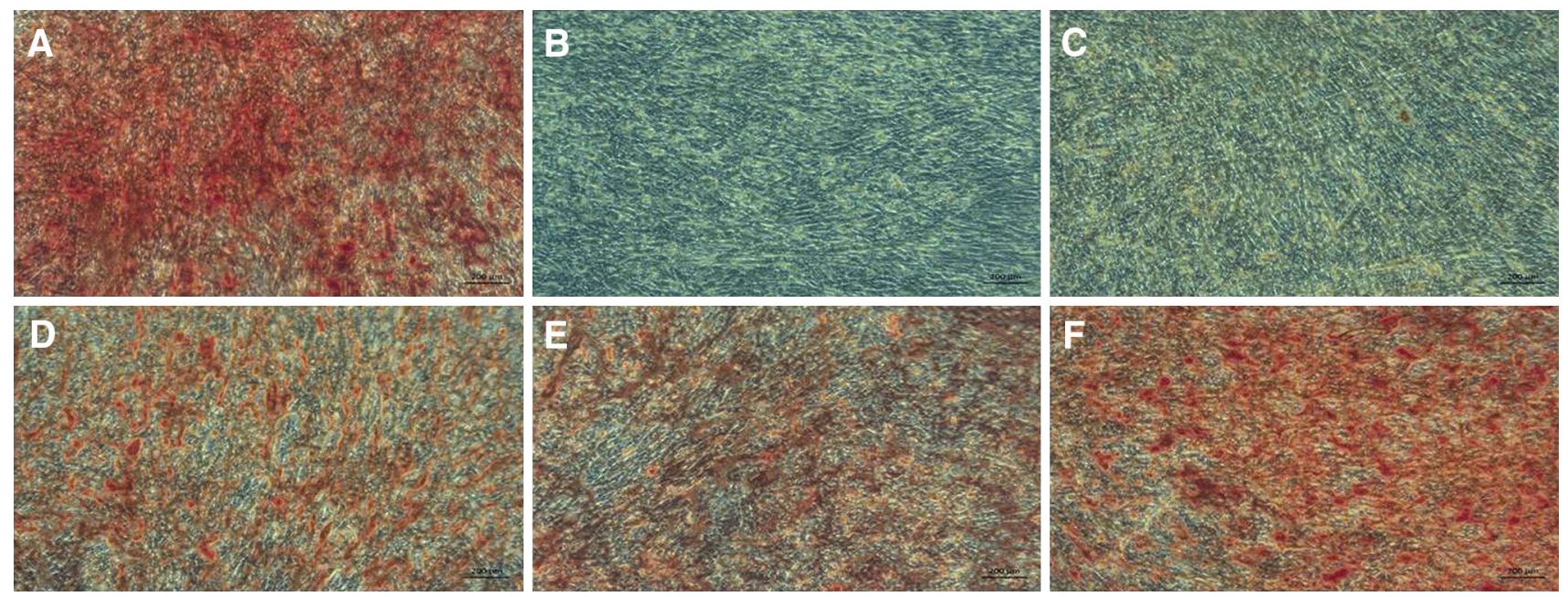

Fig. 9 Alizarin Red staining on 21th day of ADSCs osteogenesis (calcium deposits formed in the differentiated cells (osteoblasts) are red-orange/red color). A Positive control (differentiated cells without preincubation with HCP in osteogenic induction medium). B Negative control (cells cultured in culture medium without preincubation with
HCP). C-E Differentiated cells preincubated with HCP before the beginning of the differentiation process. C $10^{-4} \mathrm{M} \mathrm{HCP}$. D $10^{-5} \mathrm{M}$ HCP. E $10^{-6}$ M HCP. F $10^{-7}$ M HCP. Images acquired by inverted light microscope (ZEISS AX10, Poland; magnification $\times 100$ )
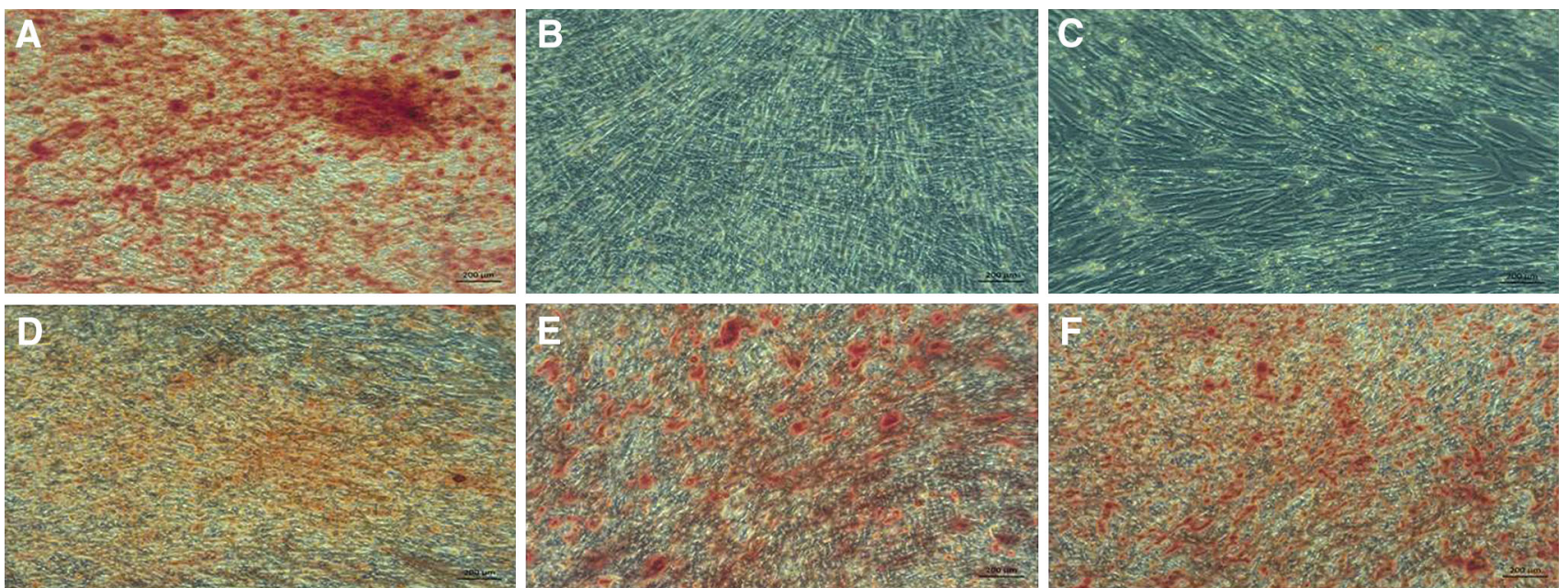

Fig. 10 Alizarin Red staining on 21th day of UCSCs osteogenesis (calcium deposits formed in the differentiated cells (osteoblasts) are orange/red color). A Positive control (differentiated cells without preincubation with HCP in osteogenic induction medium). B Negative control (cells cultured in culture medium without preincubation with
HCP). C-E Differentiated cells preincubated with HCP before the beginning of the differentiation process. C $10^{-4} \mathrm{M} \mathrm{HCP}$. D $10^{-5} \mathrm{M}$ HCP. E $10^{-6}$ M HCP. F $10^{-7}$ M HCP. Images acquired by inverted light microscope (ZEISS AX10, Poland; magnification $\times 100$ )
Table 2 ADSCs and UCSCs Alizarin Red staining intensity (microscopic evaluation)

\begin{tabular}{lllllll}
\hline $\begin{array}{l}\text { Stem } \\
\text { cells }\end{array}$ & Control positive & Control negative & HCP & & \\
\cline { 3 - 6 } & & & $10^{-4} \mathrm{M}$ & $10^{-5} \mathrm{M}$ & $10^{-6} \mathrm{M}$ & $10^{-7} \mathrm{M}$ \\
\hline ADSCs & ++++ & - & - & ++ & ++ & +++ \\
UCSCs & ++++ & - & - & ++ & ++ & +++ \\
\hline
\end{tabular}

reduced viability, proliferation and differentiation potential. In contrast, Legzdina et al. [25] did not found agerelated decrease in potential of growth and differentiation of ADSCs isolated from human donors. Authors concluded that the differences between studies from different laboratories resulted from donor-specificity and the intricacy in the dynamics of cell subsets present in ADSC population. In addition it has been shown that various diseases may 
affect number, proliferation and differentiation properties of MSCs [26].

In presented here study we evaluated how exposure to lipophilic substance HCP affects quality of MSCs (ADSCs and UCSCs). We found three major effects of HCP on MSCs cultured in vitro: (1) high toxicity (cell growth arrest) in the highest doses, (2) increased apoptosis especially pronounced in UCSCs, (3) inhibition of differentiation into osteoblasts, which persisted after HCP had been removed before induction of differentiation. The latter is of particular interest because it suggests that HCP causes long-lasting, or even permanent, changes in cell homeostasis, which inhibits the differentiation process. Similar long-lasting effects of the milieu on MSCs' quality had been reported by others. Kim et al. [27] compared UCSCs isolated from gestational diabetes mellitus (GDM) and healthy pregnant women (N). GDM-UCSCs displayed decreased cell growth and significantly lower osteogenic and adipogenic differentiation potential then N-UCSCs. Furthermore, GDM-UCSCs exhibited earlier cellular senescence, low mitochondrial activity and reduced expression of the mitochondrial regulatory genes. Also Liu et al. [28] reported that MSCs isolated from bone marrow gestational diabetes mellitus patients exhibited lower growth than those isolated from a control group.

Relatively little is known about the biochemical mechanisms of toxicity of $\mathrm{HCP}$ at the cellular and molecular level. According to the literature, $\mathrm{HCP}$ is a potent hemolytic agent inducing hemolysis by association witch the cellular membrane of red blood cells (RBC). Moreover, residues of HPC were detected in the cytoplasm of surviving RBCs [29]. Amdur et al. [30] showed that HCP binds tightly to cell membrane resulting in the loss of ion gradients. The major effect of HCP is the modification of the permeability of cellular membrane, and in consequence, the disruption of the efflux of monovalent cations such as $\mathrm{K}^{+}$and $\mathrm{Na}^{+}$. The ultimate result of this process is osmotic swelling and subsequent hemolysis of RBCs. Osmoregulation of the erythrocytes is based on the balance between the active and passive transport of $\mathrm{K}^{+}$and $\mathrm{Na}^{+}$. Hemolysis may be the effect of the disruption of this balance [31]. The defective ion transport can lead to: direct inhibition of $\left(\mathrm{K}^{+}-\mathrm{Na}^{+}\right)$-activated and $\mathrm{Mg}^{2+}$-dependent ATPase and decreased efficiency of metabolic reactions. These in turn lead to inhibition of oxidation and changes in permeability of the cellular membrane [29]. Toxic mechanism of HCP associated with modifications of cell membrane permeability and mitochondrial function partially explains the results in our present study.

The HCP also influences the cellular energetic processes. It has been shown that HCP in micromolar concentration upregulated respiration of rat liver and calf brain's mitochondria [32]. In higher concentrations, the
HCP acted as a potent uncoupler of oxidative phosphorylation in mitochondria and inhibited mitochondrial respiration. The chemical structure of $\mathrm{HCP}$ is similar to that of pentachlorothiophenol and halogenated phenols, which are known as uncoupling agents of mitochondrial oxidative phosphorylation [32]. We observed that $10^{-4} \mathrm{M} \mathrm{HCP}$ caused both necrosis and apoptosis of MSCs while the lower concentration $\left(10^{-5} \mathrm{M}\right)$ of HCP induced apoptosis. It is well known that disruption of mitochondrial functions is a major factor inducing apoptosis [33]. One of the mechanism by which HCP may affect cell apoptosis is its impact on Wnt/ $\beta$-catenin classic pathway [34]. Park et al. [35] reported that HCP addition to colon cancer cell line inhibited Wnt/-catenin signaling via degradation of the intracellular $\beta$-catenin which was independent of GSK-3 and $\beta$-TrCP activation. Moreover HCP treatment inhibited proliferation of colon cancer cells. Wnt/ $\beta$-catenin signaling pathway regulates function of $\mathrm{T}$ cells transcription factor (TCF) and affects cellular processes such as embryogenesis, survival, differentiation and proliferation in cells [36]. This may also partly explain our results: attenuated proliferation and differentiation after HCP addition.

We also showed that not only a constant presence of $10^{-4} \mathrm{M} \mathrm{HCP}$ in the differentiating medium inhibited MSCs osteogenesis but that also preincubation (for 4-5 days only) of MSCs with the $10^{-4} \mathrm{M} \mathrm{HCP}$ inhibited osteogenesis. This suggests that HCP causes permanent changes in metabolism or genetics of MSCs. Because HCP is permanently present in environment and accumulates in human body its harmful effects on MSCs have to be taken into consideration before medical application.

\section{Compliance with ethical standards}

Conflict of interest The authors declare no conflict of interest.

Ethical statement Protocol for isolation of fat tissue was approved by IV Local Ethics Committee (IV) on Animal Testing, National Medicines Institute, Warsaw, Poland (Permission No. 79/2012). Protocol for use human tissues in research was approved by Bioethical Commission, Medical University of Warsaw, Poland (Permission No. 70/2012).

Open Access This article is distributed under the terms of the Creative Commons Attribution 4.0 International License (http://crea tivecommons.org/licenses/by/4.0/), which permits unrestricted use, distribution, and reproduction in any medium, provided you give appropriate credit to the original author(s) and the source, provide a link to the Creative Commons license, and indicate if changes were made.

\section{References}

1. Tabar V, Studer L. Pluripotent stem cells in regenerative medicine: challenges and recent progress. Nat Rev Genet. 2014;15:82-92. 
2. Hirschi KK, Li S, Roy K. Induced pluripotent stem cells for regenerative medicine. Annu Rev Biomed Eng. 2014;16:277-94.

3. La Merrill M, Emond C, Kim MJ, Antignac JP, Le Bizec B, Clément K, et al. Toxicological function of adipose tissue: focus on persistent organic pollutants. Environ Health Perspect. 2013;121:162-9.

4. Kahn CM. Scott line. The merck veterinary manual. 10th ed. New York: Merck \& Co; 2011. p. 2347.

5. Ekwall B, Clemedson C, Crafoord B, Ekwall B, Hallander S, Walum E, et al. MEIC evaluation of acute systemic toxicity: part $\mathrm{V}$. Rodent and human toxicity data for the 50 reference chemicals. Altern Lab Anim. 1988;26:571-616.

6. Bethesda MD. AHFS drug information 2011. 7th ed. Texas: American Society of Health-System Pharmacists; 2011. p. 3536.

7. Lokanatha V, Sailaja P, Rajendra W. In vitro kinetics of the rat brain succinate dehydrogenase inhibition by hexachlorophene. J Biochem Mol Toxicol. 1999;13:303-6.

8. DiMaio VJ, Mullick FG, Henry LD. Hexachlorophene poisoning. J Forensic Sci. 1973;18:303-8.

9. Gronthos S, Franklin DM, Leddy HA, Robey PG, Storms RW, Gimble JM. Surface protein characterization of human adipose tissue-derived stromal cells. J Cell Physiol. 2001;189:54-63.

10. Ishige I, Nagamura-Inoue T, Honda MJ, Harnprasopwat R, Kido M, Sugimoto M, et al. Comparison of mesenchymal stem cells derived from arterial, venous, and Wharton's jelly explants of human umbilical cord. Int J Hematol. 2009;90:261-9.

11. Lewicki S, Leśniak M, Machaj EK, Antos-Bielska M, Trafny EA, Kocik J, et al. Physical properties and biological interactions of liposomes developed as a drug carrier in the field of regenerative medicine. J Liposome Res. 2017;27:90-8.

12. Kim EK, Lim S, Park JM, Seo JK, Kim JH, Kim KT, et al. Human mesenchymal stem cell differentiation to the osteogenic or adipogenic lineage is regulated by AMP-activated protein kinase. J Cell Physiol. 2012;227:1680-7.

13. Wang J, Ye Y, Tian H, Yang S, Jin X, Tong W, et al. In vitro osteogenesis of human adipose-derived stem cells by coculture with human umbilical vein endothelial cells. Biochem Biophys Res Commun. 2011;412:143-9.

14. Tohill M, Mantovani C, Wiberg M, Terenghi G. Rat bone marrow mesenchymal stem cells express glial markers and stimulate nerve regeneration. Neurosci Lett. 2004;362:200-3.

15. Van de Ven C, Collins D, Bradley MB, Morris E, Cairo MS. The potential of umbilical cord blood multipotent Stem cells from non- hematopoietic tissue and cell regeneration. Exp Hematol. 2007;35:1753-65.

16. Tuan RS, Boland G, Tuli R. Adult mesenchymal stem cells and cell-based tissue engineering. Arthritis Res Ther. 2003;5:32-45.

17. Strem BM, Hicok KC, Zhu M, Wulur I, Alfonso Z, Schreiber RE, et al. Multipotential differentiation of adipose tissue-derived stem cells. Keio J Med. 2005;54:132-41.

18. Nataloni R. Adipose stem cell developments overseas open new doors for cosmetic surgery. CosmetSurg Times. 2010;1-2. http:// aestheticchannel.modernmedicine.com/cosmetic-surgerytimes/ news/modernmedicine/modern-medicine-feature-articles/adiposestem-cell-develo?page=full.

19. Afizah H, Yang Z, Hui JH, Ouyang HW, Lee EH. A comparison between the chondrogenic potential of human bone marrow stem cells (BMSCs) and adipose-derived stem cells (ADSCs) taken from the same donors. Tissue Eng. 2007;13:659-66.

20. Lendeckel S, Jödicke A, Christophis P, Heidinger K, Wolff J, Fraser JK, Hedrick MH, et al. Autologous stem cells (adipose) and fibrin glue used to treat widespread traumatic calvarial defects: case report. J Craniomaxillofac Surg. 2004;32:370-3.

21. Alt EU, Senst C, Murthy SN, Slakey DP, Dupin CL, Chaffin AE, et al. Aging alters tissue resident mesenchymal stem cells properties. Stem Cell Res. 2012;8:215-25.

22. Li Y, Charif N, Mainard D, Bensoussan D, Stoltz JF, de Isla N. Donor's age dependent proliferation decrease of human bone marrow mesenchymal stem cells is linked to diminished clonogenicity. Biomed Mater Eng. 2014;24:47-52.

23. Paxson JA, Gruntman AM, Davis AM, Parkin CM, Ingenito EP, Hoffman AM. Age dependence of lung mesenchymal stromal cell dynamics following pneumonectomy. Stem Cells Dev. 2013;22:3214-25.

24. Choudhery MS, Badowski M, Muise A, Pierce J, Harris DT. Donor age negatively impacts adipose tissue-derived mesenchymal stem cell expansionand differentiation. J Transl Med. 2014; $12: 8$.

25. Legzdina D, Romanauska A, Nikulshin S, Kozlovska T, Berzins U. Characterization of senescence of culture-expanded human adipose-derived mesenchymal stem cells. Int $\mathrm{J}$ Stem Cells. 2016;9:124-36.

26. Chen HT, Lee MJ, Chen CH, Chuang SC, Chang LF, Ho ML, et al. Proliferation and differentiation potential of human adiposederived mesenchymal stem cells isolated from elderly patients with osteoporotic fractures. J Cell Mol Med. 2012;16:582-93.

27. Kim J, Piao Y, Pak YK, Chung D, Han YM, Hong JS, et al. Umbilical cord mesenchymal stromal cells affected by gestational diabetes mellitus display premature aging and mitochondrial dysfunction. Stem Cells Dev. 2015;24:575-86.

28. Liu Y, Li Z, Liu T, Xue X, Jiang H, Huang J, et al. Impaired cardioprotective function of transplantation of mesenchymal stem cells from patients with diabetes mellitus to rats with experimentally induced myocardial infarction. Cardiovasc Diabetol. 2013;12:40.

29. Miller TL, Buhler DR. Effect of hexachlorophene on monovalent cation transport in human erythrocytes a mechanism for hexachlorophene-induced hemolysis. Biochim Biophys. 1974;352:86-96.

30. Casarett LJ, Doull J, Amdur MO, Klaassen CD. Casarett and doull's toxicology. 4th ed. New York: Pergamon Press; 1991. p. 421.

31. Tosteson DC. The cellular functions of membrane transport. 4th ed. New York: Prentice-Hall; 1964. p. 3-22.

32. Cammer W, Moore CL. The effect of hexachlorophene on the respiration of brain and liver mitochondria. Biochem Biophys Res Commun. 1972;46:1887-94.

33. Wu YJ, Wong BS, Yea SH, Lu CI, Weng SH. Sinularin induces apoptosis through mitochondria dysfunction and inactivation of the $\mathrm{pI} 3 \mathrm{~K} / \mathrm{Akt} / \mathrm{mTOR}$ pathway in gastric carcinoma cells. Mar Drugs. 2016;14:E142.

34. Logan CY, Nusse R. The Wnt signaling pathway in development and disease. Annu Rev Cell Dev Biol. 2004;20:781-810.

35. Park S, Gwak J, Cho M, Song T, Won J, Kim DE, et al. Hexachlorophene inhibits Wnt/ $\beta$-catenin pathway by promoting Siahmediated $\beta$-Catenin degradation. Mol Pharmacol. 2006;70:960-6.

36. Zimmerman ZF, Kulikauskas RM, Bomsztyk K, Moon RT, Chien AJ. Activation of $\mathrm{Wnt} / \beta$-catenin signaling increases apoptosis in melanoma cells treated with trail. PLoS One. 2013;8:e69593. 